\title{
Perlindungan Hukum Situs Bawah Air Leato / Japanese Cargo Wreck
}

\author{
Jufryanto Puluhulawa ${ }^{1}$, Mellisa Towadi ${ }^{2}$, dan Vifi Swarianata ${ }^{3}$ \\ ${ }^{1,2,3}$ Fakultas Hukum, Universitas Negeri Gorontalo \\ Corresponding author. Email: jufryantopuluhulawa@ung.ac.id
}

Naskah diterima: 23-10-2020; revisi: 07-12-2020; disetujui: 16-12-2020

DOI: https://doi.org/10.46257/jrh.v24i2.137

\begin{abstract}
Abstrak
Kota Gorontalo memiliki situs bawah air Leato, yang dikenal juga dengan sebutan situs kapal tenggelam Japanese Cargo Wreck. Namun realitasnya, belum ada produk hukum yang menata prosedur penyelaman di lokasi situs bawah air Leato / Japanese Cargo Wreck. Rumusan masalah dalam penelitian ini, bagaimana model regulasi wisata minat khusus scuba diving kaitannya dengan optimalisasi perlindungan hukum situs bawah air Leato / Japanese Cargo Wreck? Metode penelitian yang digunakan metode penelitian normatif. Tujuan penelitian yaitu mengkaji urgensi optimalisasi perlindungan hukum situs bawah air Leato / Japanese Cargo Wreck melalui pembuatan regulasi hukum dan mendeskripsikan model regulasi wisata minat khusus scuba diving kaitannya dengan optimalisasi perlindungan hukum situs bawah air Leato / Japanese Cargo Wreck. Kegunaan penelitian memberikan kepastian hukum. Hasil kajian, realitasnya melalui langkah hukum yang progresif yakni menghadirkan regulasi hukum prosedur penyelaman rekreasi di lokasi situs bawah air Leato / Japanese Cargo Wreck dalam rangka menyikapi pesatnya pertumbuhan industri selam beserta potensinya. Model regulasi hukum prosedur penyelaman rekreasi di lokasi situs bawah air Leato / Japanese Cargo Wreck sebagai sebuah proses pembangunan hukum yang ditujukan untuk menata aktivitas hukum ke arah yang lebih baik dan kontributif khususnya terkait kesinambungan pemanfaatan situs bawah air Leato / Japanese Cargo Wreck dibidang wisata bahari minat khusus Scuba Diving tanpa mengenyampingkan pelestariannya dan juga status hukumnya sebagai kawasan konservasi maritim. Terdapat kebijakan-kebijakan hukum baik internasional maupun nasional yang dapat dijadikan landasan formulasi regulasi dan salah satunya yakni regulasi jalur penyelaman di U.S.A.T. Liberty di Tulamben, Provinsi Bali. Kesimpulan, memiliki Regulasi hukum guna optimalisasi perlindungan hukum situs bawah air Leato / Japanese Cargo Wreck sekaligus memaksimalkan potensinya pariwisatanya. Model regulasi dapat menjadikan menjadikan U.S.A.T Liberty di Tulamben, Bali sebagai percontohan penerapan regulasi prosedur menyelam pada situs bawah air. Sekaligus pengelolaannya dibidang pariwisata.
\end{abstract}

Kata kunci: perlindungan hukum, situs bawah air leato, Japanese Cargo Wreck, tantangan, solusi. 


\title{
The Legal Protection of The Leato Underwater Site / Japanese Cargo Wreck
}

\begin{abstract}
Gorontalo City has the Leato Underwater Site, which is also known as the Japanese Cargo Wreck sinking site. But in reality, there is no legal product that regulates the diving procedure at the Leato Underwater Sitel Japanese Cargo Wreck. The formulation of the problem in this study, how is the regulatory model for scuba diving special interest tourism related to the optimization of the legal protection of the Leato Underwater Site / Japanese Cargo Wreck? The research method used is the normative research method. The purpose of this research is to examine the urgency of optimizing the legal protection of the Leato Underwater Site / Japanese Cargo Wreck through the making of legal regulations and describing the model of scuba diving special interest tourism regulation concerning optimizing the legal protection of the Leato Underwater Site / Japanese Cargo Wreck. The utility of research provides legal certainty. The results of the study, in reality, are through progressive legal steps, namely presenting legal regulations on recreational diving procedures at the location of the Leato Underwater Site / Japanese Cargo Wreck to respond to the rapid growth of the diving industry and its potential. The legal regulatory model for recreational diving procedures at the location of the Leato Underwater Site I Japanese Cargo Wreck as a legal development process aimed at managing legal activities in a better and more contributive direction, especially about the sustainable use of the Leato Underwater Site / Japanese Cargo Wreck in the marine tourism field of interest specifically for Scuba Diving without compromising its conservation and also its legal status as a maritime conservation area. Both international and national legal policies can be used as the basis for the regulatory formulation and one of them is the diving route regulation in the U.S.A.T. Liberty in Tulamben, Bali Province. In conclusion, it has a legal regulation to optimize the legal protection of the Leato Underwater Site / Japanese Cargo Wreck while maximizing its tourism potential. The regulatory model can make U.S.A.T Liberty in Tulamben, Bali a pilot application of regulations for diving procedures on underwater sites. as well as management in the field of tourism.
\end{abstract}

Keywords: legal protection, the leato underwater sites, Japanese Cargo Wreck, challenges, solutions.

\section{Pendahuluan}

Laut mempunyai makna besar bagi Indonesia, sebagaimana dijelaskan Shanti Dwi Kartika bahwasannya:

"Laut sebagai medium pemersatu wilayah NKRI, laut sebagai media transportasi dan komunikasi, laut sebagai sumber daya alam buat pengembangan perniagaan, laut sebagai otoritas pertahanan dan keamanan negara. Sehingga Indonesia mempunyai relevansi membentengi dan melindungi kedamaian nautikal guna menciptakan suasana perairan 
Indonesia yang aman dari ancaman pelanggaran wilayah, aman dari bahaya navigasi pelayaran, terlindungi dari eksploitasi dan eksplorasi ilegal terhadap sumber daya alam yang menjadi aset nautical Indonesia dan kontaminasi ekosistem, serta bebas dari perbuatan melawan hukum, baik yang berasal dari lingkup nasional maupun dari lingkup internasional." (Kartika, 2016: 151)

Peranan laut sebagai sumber daya alam yang ditujukan untuk pengembangan kegiatan perniagaan dan pergerakan perekonomian nasional maupun daerah, salah satunya adalah melalui sektor kepariwisataan. Perkembangan pariwisata di dunia berdasarkan data World Travel \& Tourism Council (World Travel \& Tourism Council, 2020) "pada tahun 2019, sektor Travel \& Tourism mengalami pertumbuhan 3,5\%, melampaui pertumbuhan ekonomi global sebesar 2,5\% selama sembilan tahun berturut-turut sebagaimana tergambarkan dalam gambar berikut ini :

Gambar 1. Travel \& Tourism Regional Performance, 2019

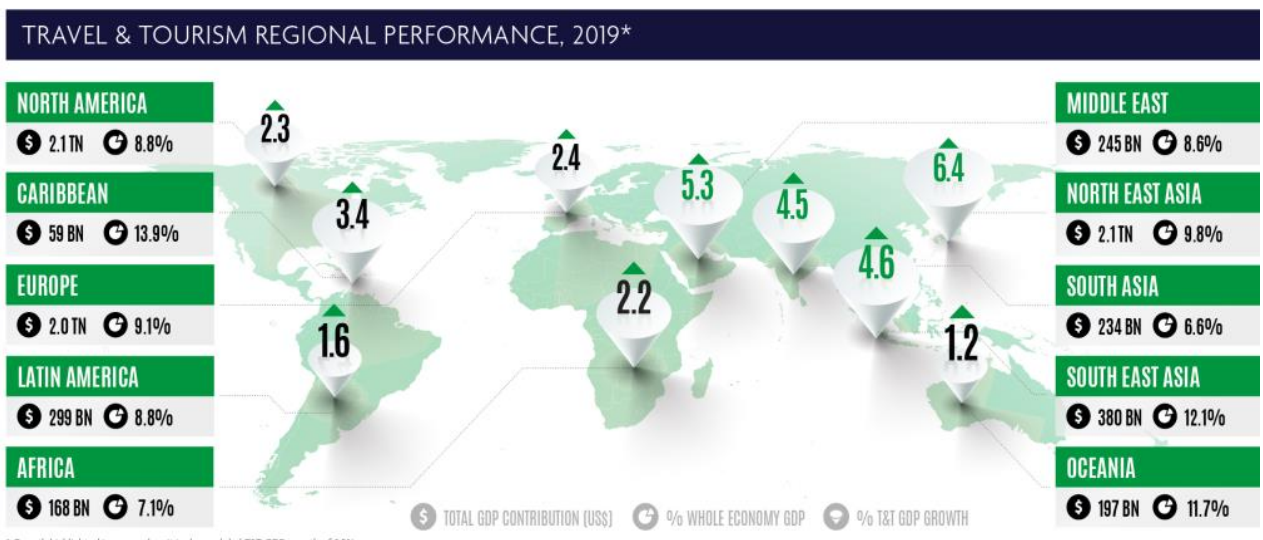

Ahmad Apriyono juga memaparkan bahwa "pada banyak negara seperti Islandia, Jepang, Meksiko, Selandia Baru, Qatar, Arab Saudi, Thailand dan Uganda memperlihatkan kecenderungan kepariwisataan menjadi primadona sekaligus menjadi sektor andalan" (Apriyono, 2016), khususnya dalam menghasilkan devisa serta rneningkatkan pendapatan masyarakat dan pemerintah melalui peningkatan usaha lokal dan pembukaan peluang investasi. Spesifiknya di Indonesia, "bidang pariwisata merupakan kontributor pendapatan negara yang memiliki kapitalisasi tinggi selain minyak dan gas.” (Apriyono, 2016) 
Memperhatikan fenomena tersebut maka sudah sepantasnya pemerintah dalam hal ini Pemerintah Provinsi Gorontalo memberikan perhatian lebih pada sektor ini. Terlebih dalam lingkup daerah yakni Provinsi Gorontalo khususnya Kota Gorontalo memiliki potensi bawah laut yang tidak kalah menariknya dengan destinasi wisata bawah laut termasyur di Indonesia, dimana Kota Gorontalo memiliki situs bawah air Leato, yang dikenal juga dengan sebutan situs kapal tenggelam Japanese Cargo Wreck.

Terletak di Pantai Leato, Desa Leato Kota Gorontalo tepatnya pada “koordinat 0²9'9"N 1234'58"E pada kedalaman 25 meter s.d. 54 meter dengan keragaman biota laut berupa Black Diadema Urchin,Yellowback Fusilier, Blue Anthias, Clark's Anemonfish, Clearfin Lionfish, Blue Sea Star serta aneka varietas terumbu karang yakni Funnel Coral, Brain Coral, Fine Table Coral, Blue Coral, Mushroom Coral, dan terumbu karang khas Gorontalo yakni Salvador Dali Sponge Coral” (Bouty, 2015: 1) tentunya menyajikan daya tarik tersendiri bagi wisatawan dengan minat khusus Scuba Diving untuk mengeksplorasi objek wisata sekaligus cagar budaya ini, terlebih lokasinya dapat dijangkau dengan ekspedisi darat yang memakan waktu 20 menit dari pusat Kota Gorontalo menjadi nilai plus tersendiri.

Berdasarkan hasil penelitian Loka Penelitian Sumber Daya dan Kerentanan Pesisir yang dipimpin oleh Nia Naelul Hasanah, menyimpulkan bahwa:

"Lokasi situs kapal tenggelam Japanese Cargo wreck di Kota Gorontalo ini bisa diekspansi sebagai destinasi rekreasi penyelaman favorit di Kota Gorontalo khusunya dan Provinsi Gorontalo umumnya yang mempunyai nilai ekonomis dikarenakan sejumlah alasan seperti keadaan laut yang teduh dan aman sebab lokasinya terletak di teluk, perairan yang bening berefek pada jarak pandangan di bawah air cukup bagus, letak objek yang berkedudukan cukup dekat dari pusat kota, jalan masuk cukup gampang untuk melakukan penyelaman (beach entry), eksistensi situs di lokasi yang memiliki panorama yang artistik dan harmoni, limitasi mutu air juga sinkron dengan baku mutu air laut untuk wisata bahari, serta adanya antologi biological laut dimana berkedudukan dalam kualifikasi baik dan stabil yang sanggup memikat kehadiran pelancong serta akademikus dari Indonesia serta mancanegara." (Ridwan, 2014: 100) 
Berdasarkan pemantau penulis yang kemudian diperkuat juga dengan hasil wawancara dengan narasumber yakni Ta Mince, pemilik warung makan diving yang berada tepat di lokasi situs bawah air leato / Japanese Cargo Wreck, bahwa setiap minggunya selalu ada pengunjung yang melakukan kegiatan menyelam / scuba diving di lokasi tersebut guna menjelajahi keindahan bawah laut sekaligus melihat langsung bangkai kapal kapal di situs bawah air Leato / Japanese Cargo Wreck.

Hal ini tentunya bagai dua sisi koin. Pada satu aspek, fakta ini menggambarkan bahwa Kota Gorontalo memiliki kapasitas pariwisata yang berpotensi untuk dimajukan guna menambah pendapatan asli daerah (PAD) sekaligus dapat mensejahterakan masyarakat setempat melalui pemberdayaan masyarakat pesisir di sekitar lokasi objek wisata, sesuai dengan amanat Pasal 33 Undang-Undang Dasar Negara Republik Indonesia Tahun 1945 yang menekankan pada kemakmuran rakyat. Sektor pariwisata juga merupakan salah satu perangkat guna mewujudkan kesejahteraan masyarakat, sebagaimana tertuang dalam konsiderans Undang-Undang Nomor 10 Tahun 2009 tentang Kepariwisataan. Namun di aspek lainnya, eksploitasi situs bawah air Leato / Japanese Cargo Wreck melalui wisata bahari minat khusus Scuba Diving tanpa regulasi dan sistem manajemen pengelolaan yang baik akan berdampak pada degradasi kualitas objek wisata bahari mengingat objek situs bawah air Leato / Japanese Cargo Wreck merupakan peninggalan purbakala yang kondisinya sangat rentan sehingga pembangunan pariwisata daerah terkhusus pada situs bawah air Leato / Japanese Cargo Wreck butuh program terencana dan berjenjang dengan target-target yang jelas sebagaimana dimandatkan dalam Peraturan Daerah Provinsi Gorontalo Nomor 2 Tahun 2019 Tentang Rencana Induk Pembangunan Pariwisata Daerah Tahun 2019-2025.

Realitasnya, belum ada produk hukum yang menata prosedur penyelaman di lokasi situs bawah air Leato / Japanese Cargo Wreck, sebagaimana penelusuran penulis pada database Pusat Dokumentasi dan Jaringan Informasi Hukum Nasional Provinsi Gorontalo dengan alamat website https://jdihp.gorontaloprov.go.id/ tidak ditemukan regulasi terkait yang 
dimaksud. Hasil penelusuran penulis juga telah dikomfirmasi ke Bagian Perundang-Undangan Biro Hukum Provinsi Gorontalo, dimana dalam penjelasannya menyatakan bahwa hingga saat ini belum ada regulasi terkait tata cara penyelaman di situs bawah air Leato / Japanese Cargo Wreck.

Fakta ini sejalan dengan pernyataan Doddy Finalosa Yusuf, pemerhati wisata minat khusus scuba diving di Kota Gorontalo, dimana sebagai seorang instruktur selam yang telah lama berkecimpung dalam wisata minat khusus scuba diving di Kota Gorontalo, beliau menerangkan bahwa "sepengetahuan saya selama ini, belum pernah mengetahui adanya peraturan khusus yang menata proses penyelaman di lokasi situs bawah air Leato / Japanese Cargo Wreck." Hal yang sama juga diungkapkan oleh Kusbian Indradi, dari Dinas Kelautan dan Perikanan Provinsi Gorontalo yang dalam pernyataannya menegaskan:

"Belum ada regulasi hukum mengenai tata cara penyelaman di situs bawah air Leato / Japanese Cargo Wreck, yang ada hanyalah Peraturan Daerah (Perda) Provinsi Gorontalo Nomor 4 Tahun 2018 Tentang Rencana Zonasi Wilayah Pesisir dan Pulau-Pulau Kecil (RZWP3K) Provinsi Gorontalo Tahun 2018-2038 dimana dalam Pasal 29 Ayat (2) Huruf a menempatkan situs bawah air Leato / Japanese Cargo Wreck sebagai kawasan konservasi maritim."(Indradi, 2020)

Fenomena ini tentunya menimbulkan kekosongan hukum yang berarti "suatu kondisi hampa atau kekurangan reglemen / kaidah yang mengoordinasikan tatanan tertentu dalam konsorsium,"(Nasir, 2017: 173) oleh karenanya harus segera diberikan kebijakan yang solutif melalui pembangunan hukum untuk mengisi kekosongan hukum agar terlaksananya sinergitas kemajuan hukum dan perubahan masyarakat, sebagaimana gagasan Mochtar Kusumaatmadja bahwa "pembentukan hukum selalu diadaptasikan bahwa hukum laksana instrumen untuk menyelenggarakan reaktualisasi masyarakat.” (Nugroho, 2017: 371) Diperlukan andil dari pemerintah daerah untuk segera melakukan pembangunan hukum guna optimalisasi perlindungan situs bawah air Leato / Japanese Cargo Wreck yang menurut Fenty U. Puluhulawa, Jufryanto Puluhulawa dan Moh. Gufran katili merupakan langkah hukum konkrit 
kebijakan hukum responsif yakni "The law as a means of response to social provisions and the aspirations of the community dan kebijakan hukum progresif yakni The law should be able to answer the developments and requirement of the times." (Fenty Usman Puluhulawa, Jufryanto Puluhulawa, Moh. Gufran Katili, 2020: 182-200)

Kekayaan bahari yang dimiliki Kota Gorontalo khususnya pada objek situs bawah air Leato / Japanese Cargo Wreck ini haruslah mendapatkan perhatian dari pemerintah daerah terlebih lokasi tersebut memiliki daya tarik wisata sebagaimana dijelaskan dalam Pasal 1 ayat (5) Undang-undang No. 10 Tahun 2009 tentang Kepariwisataan, bahwasannya daya tarik wisata merupakan "segala sesuatu yang memiliki keunikan, keindahan, dan nilai yang berupa keanekaragaman kekayaan alam, budaya, dan hasil buatan manusia yang menjadi sasaran atau tujuan kunjungan wisatawan."

Selain itu juga, ekspansi pariwisata khususnya pada objek situs bawah air Leato / Japanese Cargo Wreck memiliki konsekuensi signifikan pada beberapa bidang, seperti kemajuan perekonomian, sosial budaya, penggunaan sumber daya alam, kapasitas dukung zona kehidupan serta pertahanan dan keamanan. Mengingat potensi pariwisata ini menurut Shanti Dwi Kartika, "bisa bertransformasi sebagai kekuatan sekaligus ancaman dengan tingkat kerawanan yang besar dan berpotensi menggoyahkan stabilitas keamanan yang dapat membahayakan keutuhan Negara Kesatuan Republik Indonesia (NKRI)." (Kartika, 2016: 144)

Berdasarkan latar belakang yang telah diuraikan maka penulis menitikberatkan penulisan ini pada dua (2) rumusan masalah yakni:

a. Apa urgensi optimalisasi perlindungan hukum situs bawah air Leato / Japanese Cargo Wreck melalui pembuatan regulasi hukum wisata minat khusus scuba diving?

b. Bagaimana model regulasi wisata minat khusus scuba diving kaitannya dengan optimalisasi perlindungan hukum situs bawah air Leato / Japanese Cargo Wreck? 
Adapun metode penelitian yang dipakai dalam penelitian ini adalah pendekatan normatif dimana pendekatan ini memusatkan kajiannya dengan melihat "hukum ibarat satu komposisi yang integral yang melingkupi seperangkat asas hukum, norma hukum dan aturan-aturan hukum” (Ali, 2002: 7)

\section{Pembahasan}

A. Urgensi Optimalisasi Perlindungan Hukum Situs Bawah Air Leato / Japanese Cargo Wreck Melalui Pembuatan Regulasi Hukum Wisata Minat Khusus Scuba Diving

\section{Optimalisasi Perlindungan Hukum Situs Bawah Air Leato / Japanese Cargo Wreck}

Tindak lanjut dari penetapan situs bawah air Leato / Japanese Cargo Wreck sebagai kawasan konservasi maritim sebagaimana dimandatkan dalam Pasal 29 ayat (2) Peraturan Daerah Provinsi Gorontalo Nomor 4 Tahun 2018 Tentang RZWP3K Provinsi Gorontalo Tahun 2018-2038 tentu salah satunya adalah dengan menghadirkan regulasi hukum yang mengatur prosedur penyelaman di lokasi situs bawah air Leato / Japanese Cargo Wreck mengingat penekanan dari penetapan kawasan konservasi maritim ini adalah pelestarian dan pemanfaatan adat serta budaya maritim yang hidup di lingkungan masyarakat pesisir dan pulau-pulau kecil. Selaras dengan pernyataan tersebut, Pasal 2 ayat (2) Peraturan Menteri Kelautan dan Perikanan Republik Indonesia Nomor PER.17/MEN/2008 tentang Kawasan Konservasi Di Wilayah Pesisir Dan Pulau-Pulau Kecil juga menjelaskan sasaran pengaturan wilayah konservasi ditujukan untuk pengamanan, konservasi, dan pendayagunaan zona tepi laut dan daratan-daratan kecil serta lingkungan hidupnya untuk mengamankan eksistensi, kesiapan, dan kelangsungan sumber daya tepi laut dan daratan-daratan kecil melalui konsistensi melindungi dan memajukan derajat mutu maupun diversitasnya.

Eksistensi dari situs bawah air Leato / Japanese Cargo Wreck ini juga dipertegas lagi dengan telah di datanya situs tersebut oleh Balai Pelestarian Cagar Budaya Gorontalo dengan nomor registrasi pendataan yakni BPCB 
GTO.75.71/ODCB.2015.10.06/00019 dengan nama Kapal Karam Leato serta nomor registrasi pendataan nasional yakni PO2017071800005 dengan nama Situs Bawah Air Leato. (Faiz, 2020) Konsekuensinya adalah situs bawah air Leato ini mendapatkan perlakuan perlindungan sebagai cagar budaya sebagaimana ketentuan yang tertuang dalam Undang-Undang Nomor 11 Tahun 2010 tentang Cagar Budaya.

Double protection yang diberikan oleh Undang-Undang Nomor 11 Tahun 2010 tentang Cagar Budaya dan Undang-Undang Nomor 27 Tahun 2007 jo Undang-Undang Nomor 1 tahun 2014 tentang Perubahan Atas Undang-Undang Nomor 27 Tahun 2007 tentang Pengelolaan Wilayah Pesisir dan Pulau-Pulau Kecil serta Peraturan Menteri Kelautan dan Perikanan Republik Indonesia Nomor PER.17/MEN/2008 tentang Kawasan Konservasi Di Wilayah Pesisir Dan Pulau-Pulau Kecil yang diaplikasikan turunan pengaturannya dalam Peraturan Daerah Provinsi Gorontalo Nomor 4 Tahun 2018 Tentang RZWP3K Provinsi Gorontalo Tahun 2018-2038, semakin mempertegas urgensi hadirnya regulasi hukum yang mengatur prosedur penyelaman di lokasi situs bawah air Leato / Japanese Cargo Wreck sebagai aturan turunan yang lebih spesifik guna memberikan perlindungan yang optimal terhadap kesinambungan pelestarian situs. Terlebih dalam ruang lingkup internasional, United Nations Convention on the Law of the Sea (UNCLOS) yang telah disahkan oleh Indonesia melalui Undang-Undang Nomor 17 Tahun 1985 pada pasal 303 menyebutkan kewajiban state parties untuk melindungi peninggalan arkeologi atau benda bersejarah yang ditemukan di laut.

Perlindungan hukum sangatlah diperlukan dimana bagi Satjipto Rahardjo, "perlindungan hukum merupakan usaha untuk mengintegrasikan beragam kebutuhan dalam asosiasi agar tidak terjadi benturan antarkebutuhan dan bisa menikmati semua hak-hak yang diberikan oleh hukum." (Nola, 2016: 40) Hal ini mengingat posisi situs yang memiliki nilai historis, pendidikan maupun budaya pada satu sisi dan nilai ekonomis disisi lainnya. 
Bernilai ekonomis dikarenakan, jika menilik ke provinsi tetangga yakni Sulawesi Utara, "medio 2015, turis luar negeri yang berkunjung ke Manado totalnya 27.059 orang. Angka ini naik signifikan jadi 127.879 turis luar negeri di tahun 2018. Sembilan puluh persen (90\%) turis luar negeri yang berkunjung, datang dari Tiongkok dan kegiatan terbesarnya adalah melaksanakan wisata selam." (Asyraf, 2019) Jelas ini adalah kesempatan yang sangat bagus untuk menaikkan pendapatan asli daerah (PAD) sekaligus mensejahterahkan rakyat, sebagaimana diutarakan oleh Frans Rattu bahwa "bersandarkan data Kementerian Pariwisata menuturkan kapasitas usaha scuba diving mengantongi 35\% dari keseluruhan kadar potensi wisata bahari di dalam negeri yang diduga menyentuh US\$ 4 miliar”, (Ginting, 2019) sedangkan untuk kapasitas pemasukan dari pemberdayaan kapal karam sebagai pariwisata bawah laut, sanggup memanifestasikan US\$ 800 - 126.000 per bulan per situs. (Rahadian, 2018)

Sebuah angka yang fantastis dan tentunya Provinsi Gorontalo memiliki potensi tersebut mengingat antara Provinsi Gorontalo dan Provinsi Sulawesi Utara tidak begitu jauh letaknya dan juga memiliki keanekaragaman bawah laut yang sangat kaya ragamnya bahkan Provinsi Gorontalo memiliki nilai tambah karena memiliki situs bawah air Leato / Japanese Cargo Wreck sebagai spot diving bernilai historis yang sangat jarang diketemukan di tempat lain. Oleh karenanya, "upaya pelestarian dan pemanfaatan situs kapal tenggelam perlu lebih ditingkatkan dan dikelola baik sehingga akan menjadi aset kebudayaan dan pariwisata yang memberikan nilai tambah ekonomi bagi masyarakat." (Aksa, 2007: 72-83) Fenomena ini menggambarkan bahwa ternyata tidak hanya benda muatan kapal tenggelam saja yang bernilai ekonomis tapi kapalnya pun memiliki nilai ekonomi dan dapat menyumbangkan pemasukan bagi daerah jika dikelola dengan baik.

Indonesia khususnya dalam perkembangannya saat ini memiliki situs peninggalan budaya maritim kapal karam di Negara Kesatuan Republik Indonesia ini yang telah dimanfaatkan sebagai pergelaran wisata selam yakni Bali dengan Tulambennya, Papua Barat dengan Raja Ampatnya, Jawa 
Tengah dengan Karimun Jawanya dan masih banyak lagi Berdasarkan lokasi wisata selam di Indonesia, Roby Ardiwidjaja menegaskan bahwa "wisata selam sanggup mengonversikan pendayagunaan warisan budaya kapal karam beserta kandungannya dari komersialisasi produk menjadi komersialisasi pengetahuan dan wawasan yang diperdagangkan." (Ardiwidjaja, 2017: 141)

Fakta ini semakin mempertegas bahwasannya potensi ini harus dibijaki dengan baik melalui langkah hukum yang progresif yakni menghadirkan regulasi hukum prosedur penyelaman rekreasi di lokasi situs bawah air Leato / Japanese Cargo Wreck dalam rangka menyikapi pesatnya pertumbuhan industri selam beserta potensi yang terdapat didalamnya sekaligus meningkatkan mutu pelayanan wisata selam rekreasi di lokasi situs bawah air yang wajib mencermati dimensi proteksi bagi keselamatan dan keamanan pengunjung selam rekreasi serta konservasi alam di dalam aktivitas wisata scuba diving, sebagaimana diamatkan juga dalam Peraturan Menteri Pariwisata Republik Indonesia Nomor 7 Tahun 2016 Tentang Pedoman Penyelenggaraan Wisata Selam Rekreasi.

Nia Naelul Hasanah juga menyatakan bahwa "regulasi wisata bahari dan aktivitas penyelaman di lokasi ini harus disiapkan sesegera mungkin oleh pemerintah daerah dan situs Japanese Cargo wreck ini disarankan untuk penyelam yang berpengalaman (advance diver) karena kedalaman lokasi situs yang dapat membahayakan bagi penyelam pemula yang kurang berhati-hati." (Ridwan, 2014: 99)

Selain itu, Eko Julianto S dan Sulaiman menyatakan "logam merupakan material yang rawan kerusakan akibat korosi. Apabila tidak ada penanganan terhadap cagar budaya berbahan logam, maka seiring bertambahnya usia dan kondisi lingkungan, cagar budaya tersebut beresiko rusak sehingga dapat menghilangkan nilai penting yang terkandung di dalamnya." (Eko Julianto S \& Sulaiman, 2015: 38) Senada dengan hal tersebut, berdasarkan penyelaman yang dilakukan penulis di lokasi situs, penulis mengamati bahwa objek situs bawah air Leato / Japanese Cargo 
wreck ini strukturnya sebagian besar adalah logam besi / baja yang tentunya sangat rentan akan degradasi fisik mengingat kondisinya yang telah puluhan tahun berada dibawah laut sehingga dikhawatirkan akan mengancam keselamatan penyelam.

Tentunya dengan adanya regulasi wisata minat khusus scuba diving, hal-hal yang tidak diinginkan tersebut bisa diminimalisir. Jelas ini sinergis dengan tujuan hukum dalam perspektif kemanfaatan yakni "dalam peranannya sebagai peran preservasi pengamanan kebutuhan manusia, hukum memiliki tujuan yang ingin dicapai.” (Ridwansyah, 2016: 290)

\section{Pembuatan Regulasi Hukum Wisata Minat Khusus Scuba Diving di lokasi situs bawah air Leato / Japanese Cargo Wreck}

Regulasi hukum prosedur penyelaman rekreasi di lokasi situs bawah air Leato / Japanese Cargo Wreck yang merupakan ius constituendum, diposisikan sebagai langkah hukum progresif yang sejalan dengan pandangan Satjipto Rahardjo yakni "hukum bukan untuk pribadi dan kenisacayaannya sendiri, melainkan untuk manusia, khususnya kebahagiaan manusia." (Mukhidin, 2014: 268) Melalui regulasi hukum ini tentunya diharapkan lahirnya suatu standar prosedur penyelaman di lokasi situs bawah air Leato / Japanese Cargo Wreck yang berorientasi pada perlindungan dan pelestarian situs sehingga eksistensi objek situs dapat terjaga dengan baik dan bisa terus memberikan manfaat untuk masyarakat sekitar melalui pendayagunaan dibidang pariwisata, yang implikasinya tentu adalah peningkatan kesejahteraan masyarakat, sesuai amanat Pasal 33 Undang-Undang Dasar Negara Republik Indonesia Tahun 1945 yang menekankan pada kemakmuran rakyat.

Pendayagunaan bidang pariwisata guna peningkatan kesejahteraan masyarakat ini juga selaras dengan United Nations Environment Programme (Ardiwidjaja, 2017: 134) dimana tepi laut dan rekreasi maritim juga mampu menganugerahkan keleluasaan bagi negara berkembang untuk mengabadikan dan mempertahankan lingkungan hidup dan varietas dengan 
menggunakan zona bahari (marine dan sub marine) dan guna keperluan wisata yang persisten.

Peningkatan kesejahteraan masyarakat yang difasilitasi oleh hukum ini tentunya sinergis dengan Subekti yang memiliki pemikiran bahwa "hukum itu membaktikan kepada haluan negara yang pada pokoknya adalah membuahkan kejayaan dan kegembiraan untuk masyarakatnya." (Amrunsyah, 2019: 185) Pandangan Subekti ini selaras dengan teori utilitas yang dikemukakan oleh Jeremy Bentham yang menjelaskan "kemanfaatan atau utilitas menyebutkan bahwa setiap respons tertentu adalah benar manakala mengoptimalkan atau memaksimalkan kebahagiaan, dan dikatakan keliru apabila menciptakan kebahagiaan yang menuju ke arah kemerosotan atau sedikit.” (Firmanda, 2014: 263)

Berdasarkan uraian tersebut, maka sudah selayaknya Kota Gorontalo khususnya dan Provinsi Gorontalo pada umumnya untuk memiliki Regulasi hukum prosedur penyelaman rekreasi di lokasi situs bawah air Leato / Japanese Cargo Wreck guna optimalisasi perlindungan hukum situs bawah air Leato / Japanese Cargo Wreck sekaligus memaksimalkan potensinya pariwisatanya guna memberikan manfaat terbaik bagi daerah terkhusus masyarakat pesisir disekitar lokasi situs tersebut. Selain itu, hadirnya regulasi hukum prosedur penyelaman rekreasi di lokasi situs bawah air Leato / Japanese Cargo Wreck merupakan imbas dari asas legalitas yang dianut oleh hukum di Indonesia yang pada praktiknya menekankan pada realisasi dasar hukum dalam mengatur suatu perbuatan / peristiwa hukum.

\section{B. Model Regulasi Wisata Minat Khusus Scuba Diving Kaitannya Dengan Optimalisasi Perlindungan Hukum Situs Bawah Air Leato / Japanese Cargo Wreck}

\section{Regulasi Hukum Untuk Obyek Wisata Minat Khusus Scuba Diving}

Regulasi hukum prosedur penyelaman rekreasi di lokasi situs bawah air Leato / Japanese Cargo Wreck sebagai sebuah proses pembangunan hukum yang ditujukan untuk menciptakan denyut hukum ke haluan yang lebih baik 
dan kontributif khususnya terkait kesinambungan pemanfaatan situs bawah air Leato / Japanese Cargo Wreck dibidang wisata bahari minat khusus Scuba Diving tanpa mengenyampingkan pelestariannya dan juga status hukumnya sebagai kawasan konservasi maritim maka tentunya diperlukan konstruksi model regulasinya.

Hal ini memperhatikan aplikasi dari pembangunan hukum dibidang pariwisata mulai dari tatanan kebijakan, tata hukum, perencanaan, dan pengembangan merupakan upaya untuk memperkecil resiko atau dampak negatif. Memperhatikan juga nilai strategis dari budaya maritim situs bawah air Leato / Japanese Cargo Wreck dengan mempertimbangkan kerentanannya terhadap aktivitas manusia dalam hal ini aktivitas wisata selam rekreasi. Maka regulasi hukum prosedur penyelaman rekreasi di lokasi situs bawah air Leato / Japanese Cargo Wreck ini dapat menyandarkan subtansinya pada kebijakan-kebijakan hukum pembangunan wisata selam tinggalan budaya bawah air seperti yang telah diatur oleh UNESCO, World Summit 1992 dan 2002 tentang Pembangunan berkelanjutan, ICOMOS 1999, Undang-Undang Dasar Negara Republik Indonesia Tahun 1945, UU No 10 Tahun 2009 tentang Kepariwisataan, UU No. 11 Tahun 2010 tentang Cagar Budaya, UU No. 23 Tahun 1997 tentang Pengelolaan Lingkungan Hidup, PP No 10 Tahun 1993 tentang Pelaksanaan UU No. 5 Tahun 1992 tentang Benda Cagar Budaya, selain itu patut juga memperhatikan peraturan menteri dan peraturan daerah terkait.

Dasar-dasar hukum ini dapat dijadikan acuan dalam memformulasikan regulasi hukum prosedur penyelaman rekreasi di lokasi situs bawah air Leato / Japanese Cargo Wreck. Selain dasar-dasar hukum yang telah diuraikan, peranan politik hukum dalam pembentukan regulasi ini juga cukup signifikan andilnya mengingat politik hukum memiliki keterkaitan erat dengan hukum dimasa depan atau disebut juga dengan terminologi ius constituendum dimana menurut Mia Kusuma Fitriana, "politik hukum merupakan kaidah fundamental dalam mekanisme determinasi nilai-nilai, penentuan, pembuatan dan ekspansi hukum nasional di Indonesia." 
(Fitriana, 2018: 1) Terlebih terdapat hubungan sibernatik yang melibatkan berbagai sub sistem dalam pemanfaatan dan pengembangan serta pelestarian situs bawah air Leato / Japanese Cargo Wreck.

\section{Model Regulasi Wisata Minat Khusus Scuba Diving Guna Optimalisasi Perlindungan Hukum Situs Bawah Air Leato / Japanese Cargo Wreck}

Jika mengacu pada situs U.S.A.T Liberty di Tulamben Bali yang sudah cukup lama mengembangkan pariwisata bawah airnya teristimewa wisata minat khusus Scuba Diving, poin terpenting dari regulasi ini adalah pembuatan jalur penyelaman yang tentunya ditujukan untuk melindungi situs bawah air Leato / Japanese Cargo Wreck dari potensi kerusakan yang disebabkan oleh aktivitas menyelam dan juga untuk meminimalisir potensi kecelakaan di dalam air. Jalur penyelaman situs USAT Liberty di Tulamben Bali tersebut bisa diamati dari gambar berikut: (Dermawan, 2018: 26)

Gambar 2. Jalur Penyelaman U.S.A.T Liberty di Tulamben, Bali

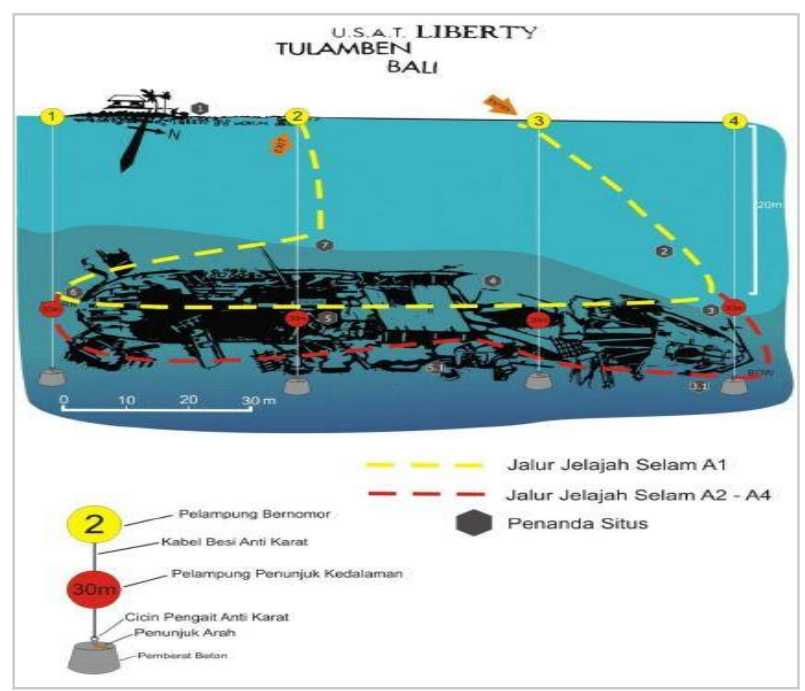

Berdasarkan jalur penyelaman situs U.S.A.T Liberty di Tulamben Bali tersebut, terlihat bahwa terdapat pembagian jalur untuk penyelam berdasarkan klasifikasi lisensi yang dimilikinya. Jika melihat pengkodean lisensi yang digunakan, maka sertifikasi lisensi Confederation Mondiale des Activites Subaquatiques (CMAS) bekerjasama dengan Persatuan Olahraga 
Selam Seluruh Indonesia (POSSI) yang digunakan sebagai dasar dalam penentuan jalur penyelaman U.S.A.T Liberty tersebut. Jenjang sertifikasi tersebut menurut Komi Kendy diklasifikasi sebagai berikut: (Kendy, 2019)

- Lisensi A1 (Open Water Scuba Diving)

- Lisensi A2 (Advanced Scuba Diving)

- Lisensi A3 (Rescue Scuba Diving)

- Lisensi A4 (Master Scuba Diving)

- Lisensi B1 (Instruktur)

- Lisensi B2 (Instruktur)

- Lisensi B3 (Instruktur)

Maka berdasarkan jenjang klasifikasi tesebut, penyelam dengan sertifikasi lisensi menyelam A1 yang bisa dikatakan sebagai pemula, dapat melakukan penyelaman berdasarkan jalur berwarna kuning yang jika melihat sketsa / gambar yang ada, hanya diperkenankan menyelam dibagian atas dari situs U.S.A.T Liberty dengan batas kedalaman yang ditoleransi adalah dua puluh (20) meter. Sedangkan bagi penyelam yang telah memiliki jam terbang yang lebih baik serta sertifikasi lisensi selam tingkat lanjut, dapat mengeksplorasi lebih dalam hingga tiga puluh (30) meter sesuai jalur bertanda merah pada sketsa/gambar tiga (3).

Tujuannya jelas yakni untuk keamanan dari penyelam itu sendiri dan juga kelestarian dari situs yang dilindungi guna pemanfaatan ekosistem dan lingkungan bawah laut yang berkesinambungan. Penyelam nyaman, objek situs bawah air Leato / Japanese Cargo Wreck juga aman.

\section{Penutup}

\section{A. Kesimpulan}

Sudah selayaknya Provinsi Gorontalo secara umum dan teristimewa Kota Gorontalo untuk memiliki Regulasi hukum prosedur penyelaman rekreasi di lokasi situs bawah air Leato / Japanese Cargo Wreck guna optimalisasi perlindungan hukum situs bawah air Leato / Japanese Cargo Wreck sekaligus memaksimalkan potensinya pariwisatanya guna memberikan manfaat terbaik 
bagi daerah terkhusus masyarakat pesisir disekitar lokasi situs tersebut. Selain itu, hadirnya regulasi hukum prosedur penyelaman rekreasi di lokasi situs bawah air Leato / Japanese Cargo Wreck merupakan imbas dari asas legalitas yang dianut oleh hukum di Indonesia yang pada praktiknya menekankan pada realisasi dasar hukum dalam mengatur suatu perbuatan / peristiwa hukum.

Model regulasi hukum prosedur penyelaman rekreasi di lokasi situs bawah air Leato / Japanese Cargo Wreck ini dapat menjadikan beberapa regulasi hukum internasional, nasional hingga daerah sebagai landasan formulasinya selain itu dapat juga menjadikan U.S.A.T Liberty di Tulamben, Bali sebagai percontohan penerapan regulasi prosedur menyelam pada situs bawah air sekaligus pengelolaannya dibidang pariwisata sehingga keamanan dari penyelam itu sendiri dan juga kelestarian dari situs yang dilindungi guna pemanfaatan ekosistem dan lingkungan bawah laut yang berkelanjutan.

\section{B. Saran}

1. Pemerintah daerah diharapkan bisa segera membuatkan regulasi hukum prosedur penyelaman rekreasi di lokasi situs bawah air Leato / Japanese Cargo Wreck.

2. Pelibatan masyarakat sekitar dalam pengelolaan pariwisata bawah air situs bawah air Leato / Japanese Cargo Wreck juga perlu untuk diperhatikan guna peningkatan kesejahteraan masyarakat.

\section{Daftar Pustaka}

Ali, A. Menguak Tabir Hukum : Suatu Kajian Filosofis dan Sosiologis, Jakarta: Ghalia Indonesia, 2002.

Aksa, L. M. "Peningkatan Manfaat dan Nilai Tambah Peninggalan Bawah Air di Kabupaten Belitung.” Varuna Jurnal Arkeologi Bawah Air, Vol. 1, 2007. Amrunsyah. "Impian Yang Terabaikan (Implementasi Dari Tujuan Hukum dan Hukum Pidana di Indonesia)." Legalite : Jurnal Perundang-Undangan dan Hukum Pidana Islam, Vol. IV, No. 1, Januari-Juni, 2019. 
Ardiwidjaja, R. "Pelestarian Tinggalan Budaya Air: Pemanfaatan Kapal Karam Sebagai Daya Tarik Wisata Selam.” Amerta : Jurnal Penelitian dan Pengembangan Arkeologi, Vol. 35, No. 2, Desember, 2017.

Eko Julianto S \& Sulaiman. “Aplikasi Sistem Perlindungan Katodik Pada Kapal Tenggelam Sebagai Benda Cagar Budaya.” Teknis, Vol. 10, No. 1, April, 2015.

Firmanda, H. "Syariah Card (Kartu Kredit Syariah) Ditinjau Dari Asas Utilitas dan Maslahah.” Jurnal Ilmu Hukum, Vol. 4, No. 2, 2014.

Fitriana, M. K. "Peranan Politik Hukum Dalam Pembentukan Peraturan Perundang-Undangan Di Indonesia Sebagai Sarana Mewujudkan Tujuan Negara.” Jurnal Legislasi Indonesia, Vol. 12, No. 2, 2018.

Kartika, S. D. "Keamanan Maritim Dari Aspek Regulasi Dan Penegakan Hukum." Negara Hukum: Membangun Hukum untuk Keadilan dan Kesejahteraan, Vol. 5, No. 2, 2016.

Mukhidin. "Hukum Progresif Sebagai Solusi Yang Mensejahterakan Rakyat." Jurnal Pembaharuan Hukum, Vol. 1, No. 3, 2014.

Nasir, G. A. "Kekosongan Hukum dan Percepatan Perkembangan Masyarakat." Jurnal Hukum Replik, Vol. 5, No. 2, 2017.

Nola, L. F. "Upaya Perlindungan Hukum Secara Terpadu Bagi Tenaga Kerja Indonesia.” Negara Hukum, Vol. 7, No. 1, 2016.

Nugroho, W. "Rekonstruksi Teori Hukum Pembangunan Kedalam Pembentukan Perundang-Undangan Lingkungan Hidup dan Sumber Daya Alam Pasca Reformasi Dalam Bangunan Negara Hukum.” Jurnal Legislasi Indonesia, Vol. 14, No. 4, 2017.

Puluhulawa, F.U., Puluhulawa, J., Katili, G. "Legal Weak Protection of Personal Data in the 4.0 Industrial Revolution Era." Jambura Law Review, Vol. 2, No. 2, 2020.

Ridwansyah, M. "Mewujudkan Keadilan, Kepastian dan Kemanfaatan Hukum dalam Qanun Bendera dan Lambang Aceh.” Jurnal Konstitusi, Vol. 13, No. 2, 2016.

Bouty, A. A. Pemetaan Potensi dan Pengembangan Prototipe Sistem Informasi Pariwisata Bawah Laut Di Kota Gorontalo. Penelitian Berorientasi 
Pengembangan Produk, Fakultas Teknik Universitas Negeri Gorontalo.

Gorontalo. 2015

Ridwan, N. N. Kajian Sumberdaya dan Kerentanan Potensi Kawasan Konservasi Maritim Situs Kapal Tenggelam di Provinsi Gorontalo. Hasil Penelitian. Balai Penelitian dan Pengembangan Sumber Daya Laut dan Pesisir Kementerian Kelautan dan Perikanan. Padang. 2014

Republik Indonesia. Undang-Undang Dasar Negara Republik Indonesia 1945. , Undang-Undang Nomor 27 Tahun 2007 tentang Pengelolaan

Wilayah Pesisir dan Pulau-Pulau Kecil. Lembaran Negara Tahun 2007 No.84. Tambahan Lembaran Negara Nomor 4739. , Undang-undang No. 10 Tahun 2009 tentang Kepariwisataan.

Lembaran Negara Tahun 2009 No.11. Tambahan Lembaran Negara Nomor 4966.

, Undang-Undang Nomor 11 Tahun 2010 tentang Cagar Budaya.

Lembaran Negara Tahun 2010 No.130. Tambahan Lembaran Negara Nomor 5168.

, Undang-Undang Nomor 1 tahun 2014 tentang Perubahan Atas

Undang-Undang Nomor 27 Tahun 2007 tentang Pengelolaan Wilayah

Pesisir dan Pulau-Pulau Kecil. Lembaran Negara Tahun 2014 No.2.

Tambahan Lembaran Negara Nomor 5490.

, Peraturan Menteri Kelautan dan Perikanan Republik Indonesia

Nomor PER.17/MEN/2008 tentang Kawasan Konservasi di Wilayah Pesisir dan Pulau-Pulau Kecil.

, Peraturan Menteri Pariwisata Republik Indonesia Nomor 7

Tahun 2016 Tentang Pedoman Penyelenggaraan Wisata Selam Rekreasi.

, Peraturan Daerah Provinsi Gorontalo Nomor 2 Tahun 2019

Tentang Rencana Induk Pembangunan Pariwisata Daerah Tahun 20192025.

, Peraturan Daerah Provinsi Gorontalo Nomor 4 Tahun 2018

Tentang Rencana Zonasi Wilayah Pesisir dan Pulau-Pulau Kecil Provinsi Gorontalo Tahun 2018-2038.

United Nations Convention on the Law of the Sea (UNCLOS) 
Faiz. Status Situs Bawah Air Leato. (J. Puluhulawa, Pewawancara), Juli 2020.

Indradi, K. Status Cagar Budaya Bawah Air Japanese Cargo Wreck. (J. Puluhulawa, Pewawancara), Juli 2020.

Mince, T. Kondisi Pengunjung Situs Bawah Air Leato / Japanese Cargo Wreck. (J. Puluhulawa, Pewawancara), Juli 2020.

Apriyono, A. "Negara yang Maju dan Berkembang dari Sektor Pariwisata" (Liputan6.com: https://www.liputan6.com/lifestyle/read/2597796/8-nega ra-yang-maju-dan-berkembang-dari-sektor-pariwisata), diakses pada 6 September 2020

Asyraf, M. "Wisata Selam Jadi Pemicu Pertumbuhan Wisman di Sulut Hingga 500\%" (Detik Travel: https://travel.detik.com/travel-news/d-4564296/ wisata-selam-jadi-pemicu-pertumbuhan-wisman-di-sulut-hingga-500), diakses pada 20 September 2020

Dermawan, A. "Pengelolaan Kapal Perang Tenggelam di Perairan Indonesia" (kkp.go.id: http://kkp.go.id/an-component/media/upload-gambar-pendu kung/djprl/HUMAS/Pengelolaan\%20Kapal\%20Perang\%20Tenggelam.p $d f$ ), diunduh pada 8 September 2020

Ginting, R. "Potensi Wisata Selam Menjadi Sumber Pendapatan Daerah" (Kawanua Inside: https://kawanuainside.com/potensi-wisata-selam-men jadi-sumber-pendapatan-daerah), diakses pada 21 September 2020

Kendy, K. "Hore, Akhirnya Saya Punya Lisensi Diving" (Komikendy.com: https://komikendy.com/hore-akhirnya-saya-punya-lisensi), diakses pada 18 Oktober 2020

Rahadian, L. "Kasus Penjarahan Bangkai Kapal Menuai Sorotan LSM Hingga DPR" (Tirto.Id: https://tirto.id/kasus-penjarahan-bangkai-kapal-menuaisorotan-lsm-hingga-dpr-cDKK), diakses pada 12 Oktober 2020

World Travel \& Tourism Council. "Economic Impact Reports" (World Travel \& Tourism Council: https://wttc.org/Research/Economic-Impact), diakses pada 29 Agustus 2020 